\title{
A Relationship between Resilience and Psychological Preparedness for Disaster among Airlangga University Health Faculty Students
}

\author{
Listyati Setyo Palupi ${ }^{1,2,3 *}$, Muhammad Noor Rahman Himawan ${ }^{1,2}$ \\ ${ }^{1}$ Personality and Social Psychology Department, Faculty of Psychology, Airlangga University, \\ Surabaya, Indonesia \\ ${ }^{2}$ Health and Environmental Sustainability Research Group, Faculty of Psychology, Airlangga \\ University, Surabaya, Indonesia \\ ${ }^{3}$ Addiction Study Centre, Airlangga University, Surabaya, Indonesia
}

\begin{abstract}
National Disaster Management Agency of Indonesia recorded 3,406 disasters events during in Indonesia reached. Research suggest that people who lived in the disasters prone area such as need to be well prepared both physically and psychologically in order to reduce the risk of disaster and ensure that the people are resilience. One of disasters prone area in east part of Java island is East Java Province. In East Java total of disasters occurred are 1537 case. Therefore, it is important to identify their psychological preparedness and resilience in this region. Thus, this study aims to determine whether there is a correlation between resilience with psychological preparedness for disaster. This research was conducted among Airlangga University Health Faculty Students in Surabaya, East Java. This research uses a quantitative approach with a survey method. The scale used are Brief Resilience Scale and Psychological Preparedness for Potential Disasters Scale. The results obtained from this study are that there is a positive linear correlation between resilience and psychological preparedness for disaster with 0.338 coefficient correlation score. That means if the level of resilience is high, the level of psychological preparedness for disaster will also be high. Vice versa.
\end{abstract}

\section{Introduction}

Indonesia is a disaster-prone country. This is due to Indonesia's geographical location which is located between three continents, namely Eurasia, Indo-Australia and the Pacific [1]. Badan Nasional Penanggulangan Bencana (BNPB) even said that the risk of disasters occurring in Indonesia for disasters was ranked first out of 265 countries previously surveyed [2]. It should also be noted that statistically the average number of disasters that

\footnotetext{
* Corresponding author: listyati.palupi@psikologi.unair.ac.id
} 
occurred in Indonesia in the last five years reached 4158 cases. Statistics also say that from 2015 to 2019 the number of disasters that occurred in Indonesia has always increased. The biggest increase occurred from 2018 to 2019, namely from 4051 cases to 9383 cases. In 2019 there were a lot of forest and land fires in Indonesia which made the number of disasters rise rapidly [3]. The disasters that occurred in Indonesia caused several impacts, both physical and non-physical. Starting from the loss of life, environmental damage, loss of property and damage to infrastructure. When a disaster occurs, it is not only the physical impact, but also the psychological impact. This impact is often not a concern because it is not as obvious as the physical impact when a disaster occurs. The psychological impact of disaster victims is in the form of a decrease in the ability of individuals to make adjustments because it is related to changes in personal, interpersonal, social, and economic life after a disaster [4]. Other research also found a significant negative relationship between loss of personal wealth, social support, and physical health with increased psychological stress after a disaster. The impact of disasters is felt in some people due to the loss of family and friends, loss of shelter and property, loss of the meaning of life, displacement and uncertainty due to loss of future orientation, and personal security [5]. The psychological impact of disasters can also cause various things such as trauma, stress, PTSD and paranoia.

Psychological impacts that have been described by previous studies are certainly an important concern as part of the disaster. Psychological effects due to disasters cause psychological shocks and unpleasant conditions for those who experience them. According to Reivich and Shatte [6], said that resilience is the ability of individuals to adapt and be tough in difficult situations. The difficult situation in question also includes a disaster situation. Several studies have shown that resilience is the key so that someone who is experiencing a disaster can return to rise from the worst conditions, adapt to the state of the disaster and get better. Research conducted by Satria and Sari [7] who conducted research in Blang Krueng village, Baitussalam Aceh Besar District, one of the disaster prone areas in Indonesia. It was found that the level of resilience held by the people in the area reached $63 \%$ which means that it is relatively high. This states that with a relatively high level of resilience, making people able to rise from adversity with the resilience factors in themselves, then this will help them to survive facing the difficulties experienced, the times of crisis in life and overcome things that can trigger stress.

Resilience is related to the psychological readiness of someone in the face of disaster. Psychological readiness for disaster explains how a person's processes and capacities, which include attention, anticipation, encouragement, intention, risk taking and management of thoughts, feelings and actions before a disaster occurs, during a disaster and after a disaster [8]. Reser and Morrissey in their research said that psychological preparedness for disasters is critical in overcoming psychological impacts that occur in a disaster. Psychological readiness also reduces psychological disorders that can occur during disasters [8]. This shows that there is a link between psychological preparedness in facing disasters and individual resilience. In a study conducted by Zulch it was found that resilience has a relationship with psychological readiness in dealing with disasters [9]. It is said that individuals who have high resilience have a high recovery rate in dealing with psychological disorders that occur after a disaster. In addition, resilience also develops positive cognitive and emotional growth in disaster victims [9].

This study seeks to determine the relationship of resilience to psychological preparedness in facing disasters among health group students because in some cases, especially in early 2020, when the COVID-19 pandemic spread around the world, due to several cases regarding the descent of students from the health group as volunteers medical. 
This was done because of the lack of medical personnel at the time of the pandemic, so additional medical personnel were needed. This study seeks to uncover how the relationship between resilience with psychological readiness and how vulnerable the students who are deployed as medical personnel to the effects of psychological disasters.

\section{Method}

This type of research used to look for the relationship of Resilience with Psychological Readiness in Health Students of Airlangga University is a quantitative-descriptive research type. This research was conducted on health students at Airlangga University in Surabaya. Total participant in this research are 219 subjects.

In this study, the instrument used to obtain the required data was an online questionnaire and the sampling technique used was the snowball sampling technique. Resilience was measured using the Brief Resilience Scale (BRS) developed by Smith, Dallen, Wiggins, Tooley, Christoper and Bernard [10] and Psychological Preparedness for Disaster (PPD) developed by Palupi [11]. The correlation technique used is Spearman Rho, a nonparametric statistical technique using BMI SPSS Statistics Version 20 for Windows.

\section{Data and Results}

Table 1. Descriptive Characteristics.

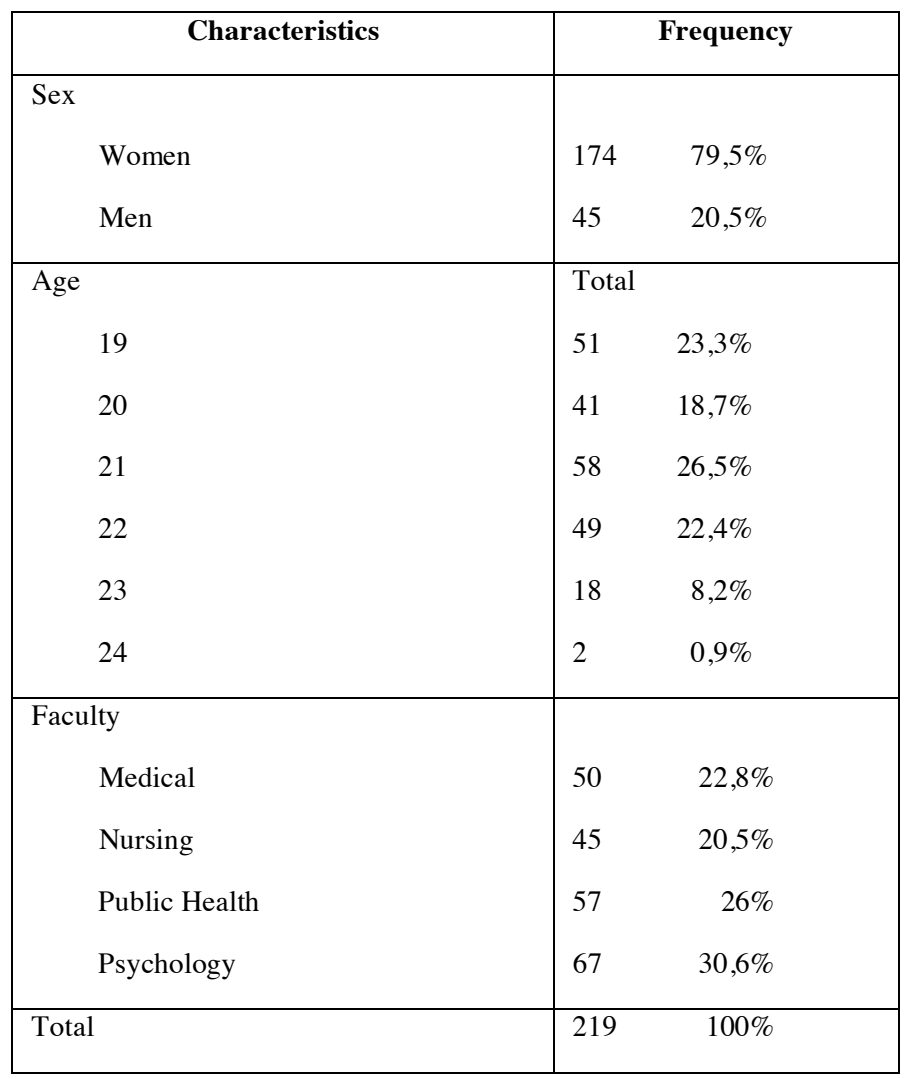


In the table above, we can see the total number of subjects obtained in this study were 219 subjects from Airlangga University health care students. it is known that the subjects in this study were dominated by female subjects with a total of 174 people or $79.5 \%$ of the whole subject, while male subjects were 45 people with a percentage of $20.5 \%$. the age of the subjects at most was at the age of 21 years, as many as 58 people with a percentage of $26.5 \%$ and the least subjects were at the age of 24 years, namely as many as 2 people with a percentage of $0.9 \%$. The subjects with the age of 19 years were 51 people with a percentage of $23.3 \%$, subjects with the age of 20 were 41 people with a percentage of $18.7 \%$, subjects with the age of 22 were 49 people with a percentage of $22.4 \%$ and subjects with the age of 23 year as many as 18 people with a percentage of $8.2 \%$. subjects in the study consisted of 4 Faculties of Health, namely Medicine, Nursing, Public Health and Psychology. The faculty origin of the most subjects is the faculty of psychology with 67 people with a percentage of $30.6 \%$. Whereas the faculty from which the subject originated at least came from the nursing faculty with 45 people with a percentage of $20.5 \%$. Subjects came from the faculty of medicine as many as 50 people with a percentage of $22.8 \%$, and the faculty of public health as many as 57 people with a percentage of $26 \%$.

Table 2. Descriptive Variables based on score.

\begin{tabular}{|lll|}
\hline & PPD & Resilience \\
\hline Total & 219 & 219 \\
Range & $37-64$ & $10-26$ \\
Mean \pm SD & $50.826 \pm 4.8996$ & $19.155 \pm 3.41$ \\
\hline
\end{tabular}

Based on table 2 above, known resilience variables have a maximum score of 26 and a minimum score of 10 with an average score of 19.155 and a standard deviation of 3.4193 . For the variable of psychological readiness to face a disaster, the maximum score reaches a score of 64 and a minimum score of 37, while for an average score of 50.826 with a standard deviation of 4.8996 .

Table 3. Correlation Test Result

\begin{tabular}{|ll|l|}
\hline & \multicolumn{1}{|c|}{ Resilience } \\
\hline PPD & Correlation Coefficient & 0.338 \\
& Sig. (2-tailed) & 0.000 \\
N & 219 \\
\hline
\end{tabular}

Based on the above table, it can be seen that the significance value between resilience and psychological preparedness in facing disasters shows .000. Correlation test can be said to be significant if the significance value is less than 0.05 . This shows that there is a significant relationship between resilience and psychological preparedness in facing disasters. The correlation coefficient number on the Spearman Rho correlation results shows .338 which shows a positive correlation and has medium strength. So it can be concluded, that there is a relationship between resilience and psychological readiness with a 
significance value of less than .005 and has a moderate correlation coefficient value, that is .338 .

\section{Discussion}

The results obtained from this study are that there is a positive linear correlation between resilience and psychological preparedness for disaster with 0.338 coefficient correlation score. That means if the level of resilience is high, the level of psychological preparedness for disaster will also be high. Vice versa. Based on the results obtained from this study, it was found that resilience has a positive correlation with psychological PREPAREDNESS FORDISASTER AMONG health students at Airlangga University. This shows that this research is in line with research conducted by previous studies. Research conducted by Hartini [12] states that resilience has a relationship with psychological readiness in dealing with disasters. Another study was conducted by NHCC [13] that community perceptions about a disaster affect the level of community resilience, and community resilience is related to community preparedness and resilience in dealing with disasters, both physically and psychologically. Other research says that resilience is related to psychological readiness in young people in Ende [14]. This research was conducted for disaster risk reduction. Other research that is in line is about community resilience in Batu Merah Village, Ambon City. This research in Batu Merah village states that disaster preparedness efforts are a form of community resilience to absorb change and persist in certain conditions in their environment.

\section{References}

1. BBC,https://www.bbc.com/indonesia/berita_indonesia/2011/08/110810_indonesia_tsu nami,10 August 2011. [Online]. Available: https://www.bbc.com/indonesia/berita indonesia/2011/08/110810 indonesia tsunami.

2. BNPB, "https://bnpb.go.id/," 10 May 2020. [Online]. Available: https://bnpb.go.id/.

3. BNPB, "https://bnpb.cloud/dibi/," 10 May 2020. [Online]. Available: https://bnpb.cloud/dibi/.

4. S. Retnowati, Intervensi Psikososial Saat bencana, Jakarta: Erlangga, (2012).

5. S. Gregor, "Resilience after Disaster," The Australian Psychological Society : Inpsych Pub, (2005).

6. K. Reivich and A. Shatte, The Resilience Factor: 7 Keys to Finding Your Inner Strength and Overcoming Life's Hurdles, Potter, (2003).

7. M. Sari and B. Satria, "RESILIENSI MASYARAKAT DENGAN DISASTER PREPAREDNESS," (2015).

8. S. A. Morrisey and J. P. Reser, "Evaluating the effectiveness of psychological preparedness advice in community cyclone preparedness materials," Australian Journal of Emergency Management, Vol. 18 No. 2,, (2003).

9. H. Zulch, "Psychological preparedness for natural hazards- improving disaster preparedness policy and practice," (2016).

10. L. S. Palupi, "Psychological Preparedness for Disaster (PPD)/ Kesiapan Psikologis Menghadapi Bencana (KPB)," (2019).

11. B. W. Smith, J. Dalen and K. Wiggins, "The Brief Resilience Scale: Assessing the Ability to Bounce Back," International Journal of Behavioral Medicine, (2008). 
12. N. Hartini, "Residents' resilience in flood prone area in Bojonegoro," Masyarakat, Kebudayaan dan Politik Vol. 30, No. 2, pp. 114-120, (2017).

13. NHCC, "https://hazards.colorado.edu/uploads/basicpage/Zulch.pdf," 23 August 2016. [Online]. Available: https://hazards.colorado.edu/uploads/basicpage/Zulch.pdf.

14. L. Ni'am and A. H. Try, "Kolaborasi Menuju Resiliensi : Pengalaman Pemuda Ende dalam Pengurangan Risiko Bencana," JURNAL STUDI PEMUDA • Vol. 2, No. 1, (2013). 